\title{
Spillovers from Japan's Unconventional Monetary Policy to Emerging Asia: a Global VAR approach
}




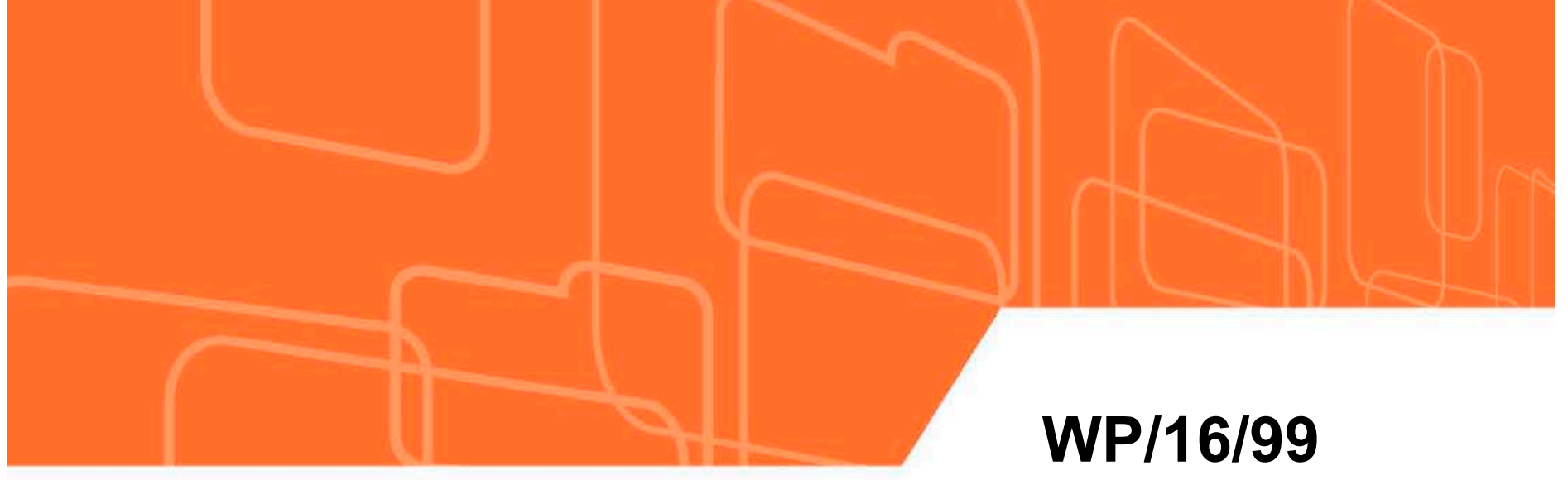

\section{IMF Working Paper}

\section{Spillovers from Japan's Unconventional Monetary Policy to Emerging Asia: a Global VAR approach}

by Giovanni Ganelli and Nour Tawk

I N T E R N A T I O N A L M O NETAR Y FU N D 


\title{
IMF Working Paper
}

Regional Office for Asia and the Pacific

\section{Spillovers from Japan's Unconventional Monetary Policy to Emerging Asia: a Global VAR approach \\ Prepared by Giovanni Ganelli and Nour Tawk}

Authorized for distribution by Odd Per Brekk

May 2016

\section{IMF Working Papers describe research in progress by the author(s) and are published to} elicit comments and to encourage debate. The views expressed in IMF Working Papers are those of the author(s) and do not necessarily represent the views of the IMF, its Executive Board, or IMF management.

\begin{abstract}
We use a Global VAR model to study spillovers from the Bank of Japan's quantitative and qualitative easing (QQE) on emerging Asia. ${ }^{1}$ Our main result is that, despite an appreciation of their currencies vis-à-vis the yen, the impact on emerging Asia's GDP tended to be positive and significant. Our results suggest that the positive effect of QQE on expectations, by improving confidence, more than offset any negative exchange rate spillover due to expenditure switching from domestic demand to Japanese goods. They also suggest that spillovers from QQE might have worked mainly through the impact of expectations and improved confidence, captured by increases in equity prices, rather than through balance sheet adjustments which might have been captured by movements in the monetary base.

JEL Classification Numbers: E5; E52; E58

Keywords: QQE; Spillovers; Emerging Asia; Japan Author's E-Mail Address: gganelli@imf.org; ntawk@imf.org

\footnotetext{
${ }^{1}$ We would like to thank Elif C. Arbatli, Dennis Botman, Odd Per Brekk, Qianying Chen, Luc Everaert, Gee Hong Joong Shik Kang, Purva Khera, Juan Martinez, Colin McKenzie, Naoko Miyake, Yoshino Naoyuki, Masao Ogaki, Jack Ree, Niklas Westelius, Sun Yan and the participants in an IMF JISPA seminar for their helpful comments on this working paper. We would also like to thank Alessandro Galesi and Vanessa Smith for their technical help with the GVAR Matlab toolbox.
} 


\section{Contents}

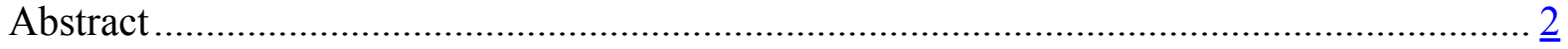

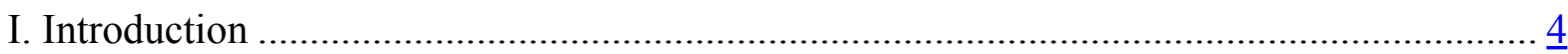

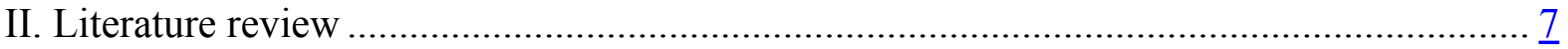

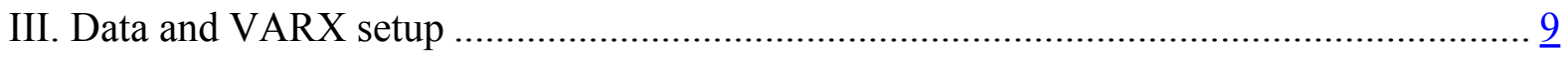

A. Unconventional monetary policy shock identification ................................................ 9

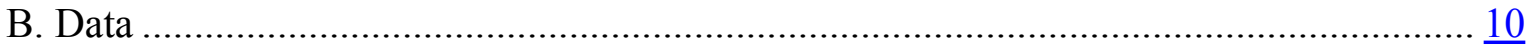

C. The weighting schemes of the GVAR model....................................................... $\frac{12}{13}$

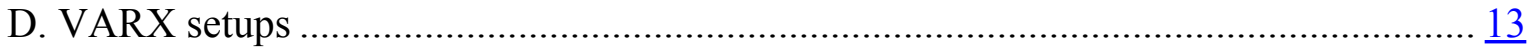

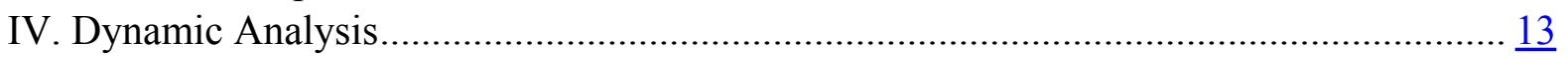

A. Structural Impulse Response........................................................................ 13

B. Impulse response results.................................................................................. 14

One negative standard deviation shock to Japan's interest rates .................................. 14

One positive standard deviation shock to Japan's monetary base .................................. $\frac{15}{15}$

One positive standard deviation shock to Japan's equity prices...................................... $\frac{15}{15}$

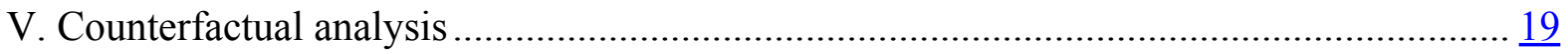

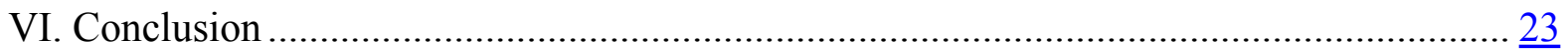

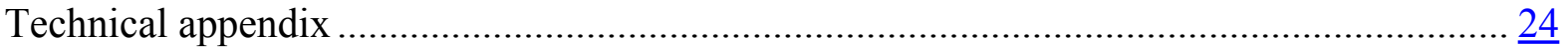

A. The GVAR model framework......................................................................... 24

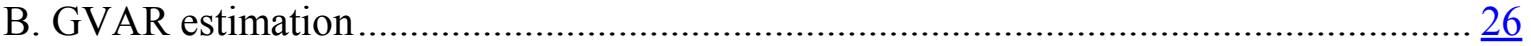




\section{INTRODUCTION}

This paper focuses on the spillover effects of Japan's unconventional monetary policy on emerging Asia. The main motivation for our analysis is that, while several papers have looked at the domestic and global impact of quantitative easing in the U.S., and at the domestic impact of Japan's unconventional monetary policy, studies of the spillovers from the latter are scarce. Given the importance of quantitative and qualitative monetary easing (QQE) in Japan's current macroeconomic policy framework, and the strong financial and trade linkages between Japan and neighboring countries, an analysis of spillovers from QQE is a highly relevant exercise.

After Prime Minister Abe came into power in late 2012, Japan has been emerging from two decades of deflation and disappointing growth, as the ambitious policy framework of Abenomics - including macroeconomic stimuli and structural reforms — was put in place. However, with interest rates at the zero-lower bound, the power of traditional monetary policy tools had become limited. As a consequence, the Bank of Japan (BoJ) embarked on new quantitative easing policies, which included the purchase of both risky assets and government securities. In April 2013, the newly appointed BoJ Governor Kuroda announced that QQE “... will double the monetary base and the amounts outstanding of Japanese government bonds (JGBs) as well as exchange traded funds (ETFs) in two years, and more than double the average remaining maturity of JGB purchases." (Figure 1.D)

Since the beginning of QQE and the launch of Abenomics, Japan has witnessed a strong depreciation of its currency (Figure 1.A), a significant surge in its equity prices (Figure 1.B), and a pick-up in inflation (Figure 1.C). The Japanese yen depreciated from $82 \mathrm{Yen} / \mathrm{USD}$ in 2012 to 119/USD yen in August 2015. Similarly, the Japan MSCI index rose from 450 points in 2012, closing at 1015 points in July 2015, while both underlying inflation and inflation expectations are currently close to one percent.

Compared to the first quantitative easing program in Japan that was launched in March 2001 and ended in March 2006, one can see that, though both QEs lead to an increase in equity prices, the current QQE had a larger impact on inflation and the exchange rate. 
Figure 1: The Japanese Economy through Abenomics and the first QE

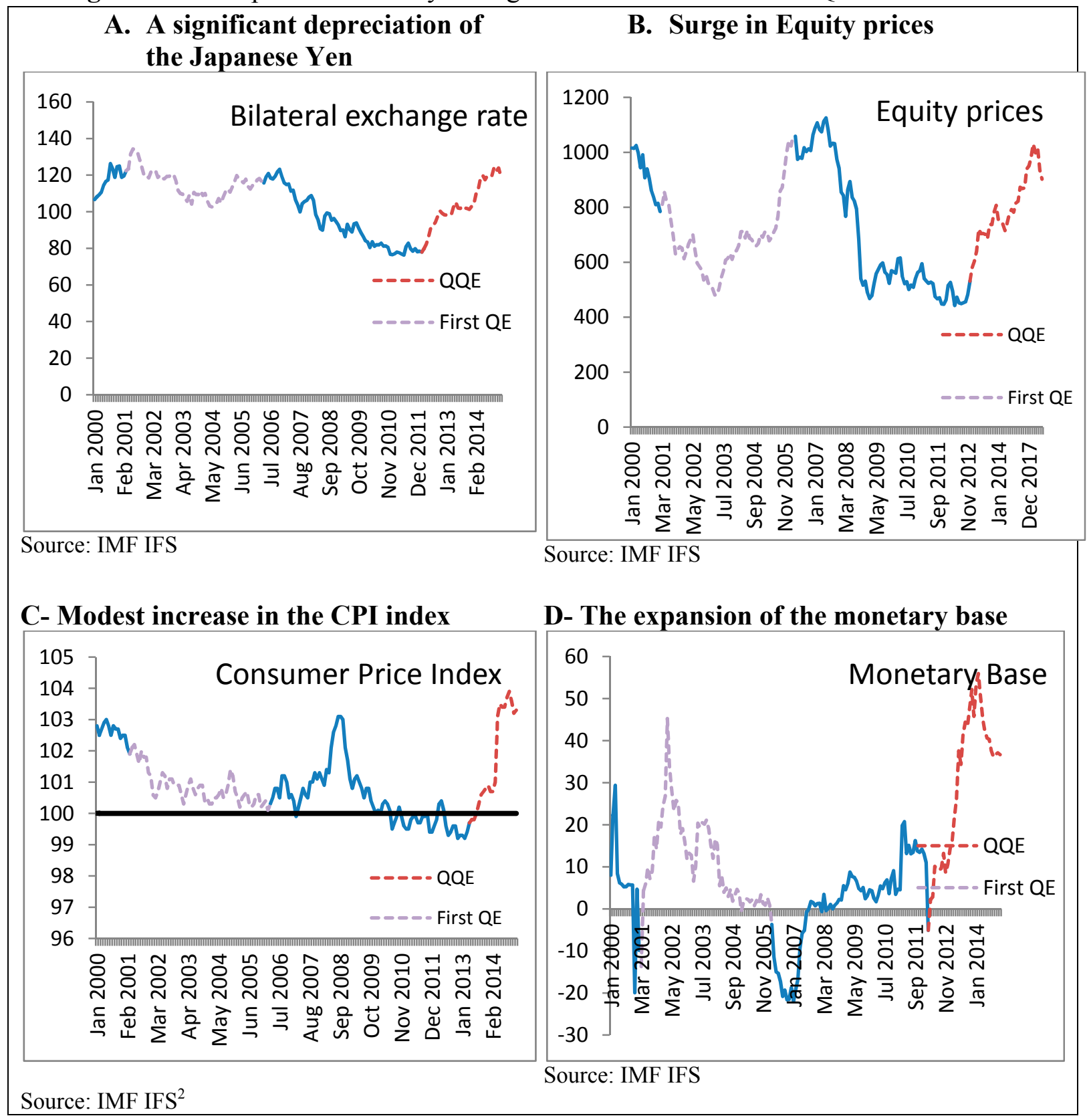

\footnotetext{
${ }^{2}$ The consumer price index includes the temporary impact of the consumption tax increase.
} 
Our main interest is to study how these developments in Japan have affected emerging Asia. In order to do this, we assess potential spillover effects from QQE using a multi-country dataset to set up a Global VAR (GVAR) model. The GVAR framework, developed by Pesaran and Smith (2004), allows examining the propagation of shocks through various macroeconomic linkages between countries. The methodology involves setting up countryspecific individual VARs, and then linking them through the inclusion of foreign variables. The latter are weighted averages of the other countries' variables, and they augment the individual country-specific VARs in order to capture the propagation of shocks. The weights on which the foreign variables are built are the countries' financial and trade exposures with regard to the other countries.

In addition to Japan, we include in our sample five ASEAN economies, namely Indonesia, Malaysia, the Philippines, Singapore, and Thailand, as well as China. The choice of countries is dictated by the availability of data. We also include the U.S. and Europe in order to control for the global impact of their respective policies, and because they are important trade and financial partners to Japan. Our GVAR model is therefore estimated for twenty countries ${ }^{3}$, using monthly data on real GDP, CPI inflation, the exchange rate, claims on the private sector, equity prices, capital inflows, short-term interest rates and the monetary base, from January 2000 up to December 2014.

We model the impact of QQE through different transition channels: the conventional monetary policy channel, the expectations channel, and the portfolio rebalancing channel. We consider a shock to interest rates as a conventional monetary policy proxy. We then model an increase in equity prices as a proxy for spillovers from QQE through the stock market channel. Using equity prices has the advantage of matching stylized facts (equity prices increased significantly during both first and second QQE periods in Japan) and of capturing the expectation channel of QQE. Finally, we look at the effects of an increase in the monetary base, as it could capture the portfolio rebalancing effects.

The main contribution of our paper is to be the first to systematically study the spillovers from Japanese QQE on emerging Asia. As we mentioned above, studies of Japan's QQE tend to focus mainly on the impact on Japan only. In addition, most studies of spillovers from unconventional monetary policy, including from the US, rely on the BIS cross-border bank lending data to proxy financial links between countries. By proxying financial linkages through the FDI channel ${ }^{4}$, we are able to include emerging Asia in our sample.

\footnotetext{
${ }^{3}$ Our sample includes Norway, Sweden, Switzerland, and the United Kingdom, and the Euro region, formed by pooling the following 8 countries: Austria, Belgium, Finland, France, Germany, Italy, the Netherlands, and Spain.

${ }^{4}$ We also proxy the portfolio investment flows as a financial channel. However, results are not reported as this data is unavailable for many emerging Asian economies.
} 
Our results show that implementation of QQE in Japan, when estimated by a positive shock to Japanese equity prices, consistently caused an increase in equity prices across emerging Asian countries, as well as an appreciation of their currencies. Most ASEAN countries experienced an increase in output and a temporary increase in inflation. Capital inflows surged in many countries. A negative shock to interest rates yielded no significant results domestically nor in foreign countries. While most of the existing literature uses interest rate changes as proxies of quantitative easing, we argue that this transmission channel is likely to be broken in Japan, because rates have been close to the zero bound for an extended period. Finally, when we used as proxy for spillovers a direct positive shock to the monetary base, we find that other than inflation, the results were weaker in magnitude and not statistically significant. While there may be technical reasons (discussed below) for the weak impact of shocks to the monetary base, one way to interpret this result is that international propagation of the effects of QQE mainly works though expectations, rather than through direct portfolio rebalancing effects, since the shocks to equity prices, which show the strongest and most significant effect, can be thought of as proxies of the expectation channel of monetary policy.

The rest of the paper is organized as follows. Section II reviews the relevant literature. Section III explains the GVAR model's setup and the data. Section IV presents the impulse response analysis and an interpretation of the results. Section V discusses the counterfactual analysis for Japan's QQE. Section VII concludes.

\section{LITERATURE REVIEW}

From a theoretical point of view, we expect a priori that unconventional monetary policy (UMP) impacts the domestic economy through its effect on the stock market, exchange rates, portfolio flows, and interest rates. The increased liquidity in the market contributes to both lowering interest rates and depreciating the domestic currency, which could stimulate capital outflows as domestic investors search for higher yields abroad. At the same time, an increase in investor confidence, working through improved expectations on economic growth due to the monetary stimulus, raises stock prices. The latter effect can also be magnified by domestic portfolio rebalancing away from bonds toward riskier assets.

We expect these channels to also determine the international spillovers of UMP. In particular, we expect that QQE in Japan generate spillovers to emerging economies through capital flows, currency appreciation, bond yields and increased stock price effects. Emerging Asian countries are expected to receive capital inflows as Japanese investors rebalance their portfolios in search of higher yields. Such inflows, as well as the yen depreciation due to monetary expansion in Japan, contribute to exchange rate appreciation in emerging Asia, with possible negative effects on their net exports. The latter negative effect, however, could be more than offset by the increased confidence associated with QQE, which could boost 
stock prices not only in Japan but also in the region. The variables which we include in our GVAR estimation are meant to capture these channels.

There is a growing body of literature which analyzes spillovers from the U.S. and Europe's unconventional monetary policies. Most studies find cross-border spillover effects in the form of large capital inflows, currency appreciation, an increase in prices and interest rates, raised equity prices and temporary increases in output. In fact, several studies have shown that, in the aftermath of the subprime financial crisis, the Fed's large scale asset purchase program (LSAP) had a strong impact on the global economy: Chen, Filardo and Zhu (2015) employ a Global VAR model and find that U.S. quantitative easing contributed to an overheating of certain economies, as well as to currency appreciation and strong capital inflows to emerging countries. Bauer and Neely (2014) show that the Fed's unconventional monetary policy announcements had a strong impact on international bond yields. Gambacorta, Hofman and Peersman (2014) use a panel structural VAR to show that the expansion in central bank balance sheets at the zero-lower bound caused a temporary increase in prices and economic activity. Glick and Leduc (2012) present evidence on the depreciation of the US dollar and British pound after announcements of LSAP, as well as of a decline in long-term interest rates.

Concerning UMP spillovers from Japan, several studies focus on the domestic impact of QQE: Fujiwara (2014), examines the effect of QQE on inflation in Japan, and finds that inflation expectations rose modestly in the short-run. Lam (2011) looks at financial indicators such as equity prices, sovereign and corporate bond yields, exchange rates and inflation, in order to assess the impact of quantitative easing by the Bank of Japan in the 2000s. He finds that these policies had no effect on raising the inflation rate or depreciating the exchange rate, but did cause stock prices to rise strongly. Joo, Kee and Choi (2014) examine the effects of QQE on Korea and find that there was little impact on trade and capital flows. Ree, Hong and Choi (2015) find that the depreciation of the Japanese Yen could increase Japan's price competitiveness in the long-run, and may be detrimental to South Korean companies in case of an appreciation of the Won. The 2015 Asia and Pacific IMF Regional Economic Outlook highlights the appreciation of currencies of several countries in Asia due to changes in monetary policies in Japan, Europe and the United States.

Global VAR models have been widely used for the study of propagation of international shocks: Eickmeyer and Ng (2011) use a GVAR to assess the impact of a tightening of credit in the US, Japan and Europe on the rest of the world by employing sign restrictions to identify their shocks. They find that while a tightening of bank credit in the U.S. substantially affected GDP of other countries; a Japanese or Euro-area credit supply shock had a weaker impact on other countries and was less statistically significant. Dees, DiMauro, Pesaran and Smith (2007) provide the theoretical framework of the GVAR model to test the transmission of shocks from the U.S. to the rest of the world. They demonstrate that financial shocks were transmitted rapidly, and usually had a larger impact on equities and bond markets compared 
to GDP and inflation. Galesi and Sgherri (2009) use financial weights based on cross-border bank lending data in order to quantify the financial spillovers across Europe through a shock to U.S. equity prices. They find strong co-movements of equity prices across Europe, but heterogeneous responses to bank credit that were country-specific. Sun, Heinz and Ho (2013) construct foreign variables from the combination of bilateral trade flows and banking exposures, in order to better capture the cross-country linkages between the Central Eastern and Southeastern Europe (CESEE) and advanced Europe countries. Most studies look at the propagation of a shock from the U.S. to the rest of the world. With the notable exception of Eickmeyer and $\mathrm{Ng}$ (2011), most of the literature relies on the BIS' cross-border bank lending data to examine the propagation of shocks through a financial channel. However, with that data unavailable for emerging Asian countries, they are forced to rely on trade weights instead, or to opt these countries out of their dataset. Therefore, most papers end up looking at spillovers to emerging Asia through the trade channel only.

\section{DATA AND VARX SETUP}

\section{A. Unconventional monetary policy shock identification}

The existing literature on the impact of quantitative easing typically uses reductions in interest rates as a proxy for monetary policy shocks. For example, Chen, Filardo, He and Zhu (2015) use the US term spread (between the 10-year and three-month Treasury yields) and the US corporate spread (between the BofA Merrill Lynch US corporate AAA bond yield and the effective federal funds rate) in order to examine the impact of the Fed's QE on the rest of the world. Dees and al (2007) compute the monetary policy shock as a cut to the US short-term interest rate. The idea behind this modeling choice is that, with an increase in the supply of money pushing down interest rates, the demand for money will be stimulated. However, studies of UMP spillovers for advanced economies have increasingly relied on other proxies for monetary policy shocks, when interest rates are at the zero-lower bound. For example, Chen, Lombardi, Ross and Zhu(2015) employ short-run sign restrictions on the Federal funds shadow rate to identify monetary policy shocks from the Fed. Still, they only registered the domestic impact of UMP, and no spillovers to other economies.

Indeed, if both the long-term interest rate and the short-term interest rate are already close to the zero lower bound, using the term spread or the corporate spread as a monetary policy indicator is not a viable strategy. As noted by Eggertsson (2008), with conventional monetary policy, a higher money supply increases demand only through lower interest rates. Therefore, at the zero lower bound, a decline in the interest rate creates no significant impact on the money supply. Rather, (unconventional) monetary policy must work through the expectation of future money supply, and thus future interest rates, so that the money supply affects spending.

In that context, one way to identify a monetary policy shock is through the "stock market channel": this channel refers to the transmission mechanism of monetary policy on stock prices. Cooley and Quadrini (1999a) use a dynamic stochastic general equilibrium model to investigate the effect of monetary policy on firms. They find that a contractionary monetary 
shock had a negative impact on the stock market index. Lastrapes (1998) and Rapach (2001) employ structural VARs with sign restrictions and come to similar findings. Furthermore, Japan's quantitative easing programs highlight the stock market channel: Japan experienced a large increase in equity prices during both quantitative easing programs. For example, Hosono and Isobe (2014) employ an event study approach using daily data to analyze the impact of monetary policy announcements on financial variables. They find that the BOJ's QQE policies had a substantial prolonged effect on stock prices. Ueda (2012) analyses the long-term effects of the BoJ's announcements on the stock market, 10 year JGB yields and the JPY/USD exchange rate. He also finds that the announcements of the BOJ had a significant and permanent impact on asset prices.

We therefore choose to model the shock of Japan's QQE through two additional alternative proxies: the increase in equity prices and the increase in the monetary base. An equity price shock has the advantage of capturing the stylized fact that, during both the first QE and the current QQE of Japan, there was a noticeable surge in equity prices in Japan. ${ }^{5}$ Furthermore, much of the transmission mechanism of QQE happens through expectations of future economic activity, which we can assume to be captured by movements in equity prices. As for the monetary base, the choice of this proxy is consistent with the fact that it is an intermediate target of QQE and Japan has almost doubled its monetary base in the last few years.

\section{B. Data}

Our dataset comprises monthly data, from January 2000 up to December 2014. The following country-specific variables are used for the GVAR model: real GDP, equity prices, CPI inflation, bank credit, the short-term interest rate, the exchange rate, the monetary base, and capital inflows. As data for the long-term interest rate is not available for many of the countries, and has been at the zero-lower bound for Japan, we opted against using it in our VARX* series. Finally, the price of oil is used as a global variable. GDP data are available on a quarterly basis. Therefore, we converted real GDP to monthly frequency by using the Chow-Lin interpolation method (with the industrial production index as a reference).

For all countries except Japan and the United States, the exchange rate variable used is the bilateral rate vis-à-vis the Japanese Yen, obtained from Bloomberg ${ }^{6}$. For Japan, the nominal effective exchange rate is used. We used the IFS consumer producer index (CPI) for all items (with 2010 as the index year). We also used the IFS claims to the private non-financial sector

\footnotetext{
${ }^{5}$ Galesi and Sgherri (2009) examine the propagation of shocks in Europe through a negative shock to the U.S. equity prices or GDP growth rate.

${ }^{6}$ For example, the Chinese Renminbi to the Japanese Yen exchange rate is expressed as JPY/CNY.
} 
series as a proxy for bank credit, as it is in a monthly frequency. We also chose to interpolate the BIS's credit to the private sector series from a quarterly to a monthly frequency, using the IFS data as a reference. Using either series yields very similar results, and we opted for the IFS monthly series in order to avoid excess seasonality created by interpolation. For equity prices, the MSCI index specific to each country is used. Only the monetary base is expressed in percentages. Finally, we looked at net flows to Emerging Asia and Japan. Positive figures indicate inflows and negative figures indicate outflows. We opted to remove the negative observations because we wanted to differentiate between inflows and outflows, and because we would not be able to express outflows in natural logarithm without adding a constant. The series are seasonally adjusted using Eviews's Census X13. ${ }^{7}$ We constructed the variables for study as follows:

Real GDP: $y=\ln \frac{G D P_{i t}}{C P I_{i t}}$

Inflation: $d p=\ln \left(C P I_{i t}\right)-\ln \left(C P I_{i, t-1}\right)$

Equity prices: $e q=\ln \left(\frac{E Q_{i t}}{C P I_{i t}}\right)$

The exchange rate: $e x=\ln \left(\frac{E_{i t}}{C P I_{i t}}\right)$

The short - term interest rate: $r=0.25 * \ln \left(1+R_{i t}^{S} / 100\right)$

\footnotetext{
${ }^{7}$ Further details about the data are included in the data appendix.
} 
Bank credit: $b c=\ln \frac{B C_{i t}}{C P I_{i t}}$

Price of oil: poil $=\ln$ Poil

Capital inflows: $c f=\ln \frac{C F}{C P I_{i t}}$

\section{The weighting schemes of the GVAR model}

A key step of the GVAR model is the inclusion of the foreign variables. For each domestic variable of each country in our sample, the corresponding foreign variable is built based on a weighted average of the corresponding variables of its partners. The weighting scheme is usually chosen to highlight the economic relationship of a particular country with another country.

Concerning the choice of transmission channels, we followed Eickmeier and $\mathrm{Ng}$ (2011) and looked into various other channels for the transmission of financial shocks.

In order to examine spillovers through the financial and trade channels, we combined the foreign direct investment flows from the IMF's Coordinated Direct Investment Survey (CDIS) with the trade flows from the IMF's direction of trade statistics. The foreign direct investment and trade flows between Japan and the other countries highlight Japan's strong linkages in Emerging Asia. As a robustness check, we also ran the GVAR with trade weights and FDI weights separately. The results are very similar to our findings when we combined the trade and FDI channels together, which suggests that the choice of weights is of secondary importance.

The bilateral trade weights are computed from the sum of imports and exports between each country. We summed the FDI inward and outward flows to create the financial weights. We opted to construct fixed weights for 2011-2014. We found that changing the time frame for the construction of weights does not lead to significant changes in the results.

Table 1 reports the weights based on the combination of trade and FDI flows between countries. The values in red highlight the larger weights. Japan shares large weights with all ASEAN countries, sometimes the largest. For example, the trade-FDI weight between Thailand and Japan is 0.28 , the largest for Thailand. Again, the Philippines and Japan share the largest trade-FDI weight (0.22) among other trade partners with the Philippines. For China, Japan ranks third after the Euro zone and the United States. These weights highlight Japan's relative importance, especially in Asia. 
Table 1: Trade and FDI weights

\begin{tabular}{lrrrrrrrrrrrrrr}
\hline \hline & China & Euro & Indonesia & Japan & Malaysia & Norway & Philippines & Singapore & Sweden & Switzerland & Thailand & UK & USA \\
China & 0.00 & 0.07 & 0.15 & 0.25 & 0.16 & 0.03 & 0.14 & 0.19 & 0.03 & 0.03 & 0.16 & 0.02 & 0.11 \\
Euro & 0.26 & 0.00 & 0.14 & 0.17 & 0.13 & 0.47 & 0.17 & 0.13 & 0.56 & 0.59 & 0.12 & 0.58 & 0.41 \\
Indonesia & 0.03 & 0.01 & 0.00 & 0.03 & 0.07 & 0.00 & 0.03 & 0.11 & 0.00 & 0.00 & 0.05 & 0.00 & 0.01 \\
Japan & 0.22 & 0.04 & 0.19 & 0.00 & 0.14 & 0.01 & 0.22 & 0.09 & 0.01 & 0.02 & 0.28 & 0.03 & 0.12 \\
Malaysia & 0.04 & 0.02 & 0.10 & 0.03 & 0.00 & 0.00 & 0.04 & 0.10 & 0.00 & 0.00 & 0.07 & 0.00 & 0.01 \\
Norway & 0.00 & 0.02 & 0.00 & 0.00 & 0.00 & 0.00 & 0.00 & 0.02 & 0.10 & 0.00 & 0.00 & 0.01 & 0.01 \\
Philippines & 0.02 & 0.00 & 0.01 & 0.01 & 0.01 & 0.00 & 0.00 & 0.02 & 0.00 & 0.00 & 0.02 & 0.00 & 0.00 \\
Singapore & 0.07 & 0.02 & 0.21 & 0.04 & 0.24 & 0.04 & 0.13 & 0.00 & 0.00 & 0.02 & 0.12 & 0.00 & 0.04 \\
Sweden & 0.01 & 0.05 & 0.00 & 0.01 & 0.00 & 0.17 & 0.00 & 0.00 & 0.00 & 0.01 & 0.01 & 0.02 & 0.02 \\
Switzerland & 0.03 & 0.14 & 0.01 & 0.01 & 0.01 & 0.02 & 0.02 & 0.02 & 0.03 & 0.00 & 0.03 & 0.04 & 0.07 \\
Thailand & 0.03 & 0.01 & 0.05 & 0.06 & 0.07 & 0.01 & 0.06 & 0.05 & 0.00 & 0.00 & 0.00 & 0.00 & 0.01 \\
UK & 0.04 & 0.28 & 0.03 & 0.05 & 0.03 & 0.15 & 0.02 & 0.05 & 0.12 & 0.08 & 0.03 & 0.00 & 0.20 \\
USA & 0.25 & 0.34 & 0.10 & 0.33 & 0.12 & 0.12 & 0.17 & 0.22 & 0.14 & 0.24 & 0.12 & 0.29 & 0.00 \\
\hline
\end{tabular}

Note: Weights for each country to another should be read vertically.

\section{VARX setups}

Except for Japan and the U.S., each country's VARX model includes the 8 domestic endogenous variables: GDP (y), CPI inflation (dp), equity prices (eq), bank credit (bc), Monetary base (mb), Short-term interest rates (r), the exchange rate (ex), and capital inflows (cf). The VARs are then augmented with the set of foreign (weakly exogenous) variables built on the flows channel, e.g. $\mathrm{y}^{*}$ or $\mathrm{dp}^{*}$, and our global variable the price of oil. All foreign variables except the price of oil are built as the weighted averages of the respective variables of the other economies, and the weights are determined through the flows channel.

The U.S. VARX vector includes all the domestic variables except for the exchange rate. However, only $\mathrm{y}^{*}$ and $\mathrm{ex} *$ enter as foreign variables in the U.S. VARX* setup. Foreign variables are not included to reflect the dominant role of the U.S. in the world economy: the U.S. affects foreign economies but is not affected by them. Finally, the price of oil is specified as an endogenous variable in the U.S. VARX*.

\section{Dynamic Analysis}

\section{A. Structural Impulse Response}

One difficulty in interpreting impulse response functions is that the shocks are typically nonorthogonal. In order to estimate orthogonal impulse responses, we identify a shock to equity prices using a recursive Cholesky scheme. Dees, diMauro, Pesaran and Smith (2007) employed structural impulse responses through a Cholesky factorization schemes for the specification of shocks. 
Following Dees, diMauro, Smith and Pesaran (2007), we chose one possible identification scheme by adopting the following ordering of the variables in the Japan bloc: short-term interest rate, equity prices, the exchange rate, bank credit, capital inflows, monetary base, inflation, and output. We experimented with a number of variable orderings (we placed equity prices as the last variable in the bloc, and then second in the ordering) and our results are largely robust. ${ }^{8}$ We chose to place the Japan model as the first country bloc in the GVAR as we wanted to look at the impact of its policies on emerging Asia. ${ }^{9}$ We also tested our results by employing short-run restrictions as a robustness check, and found our results to be robust and similar to the ones derived with a Cholesky scheme.

\section{B. Impulse response results}

\section{One negative standard deviation shock to Japan's interest rates}

We first modeled our monetary policy shock using interest rates, the central bank's conventional monetary tool. As previously mentioned, Japan's short-term and long-term interest rates had been around zero for years before breaking the lower bound into negative rates in 2016.

Figure 2: Interest rates in Japan

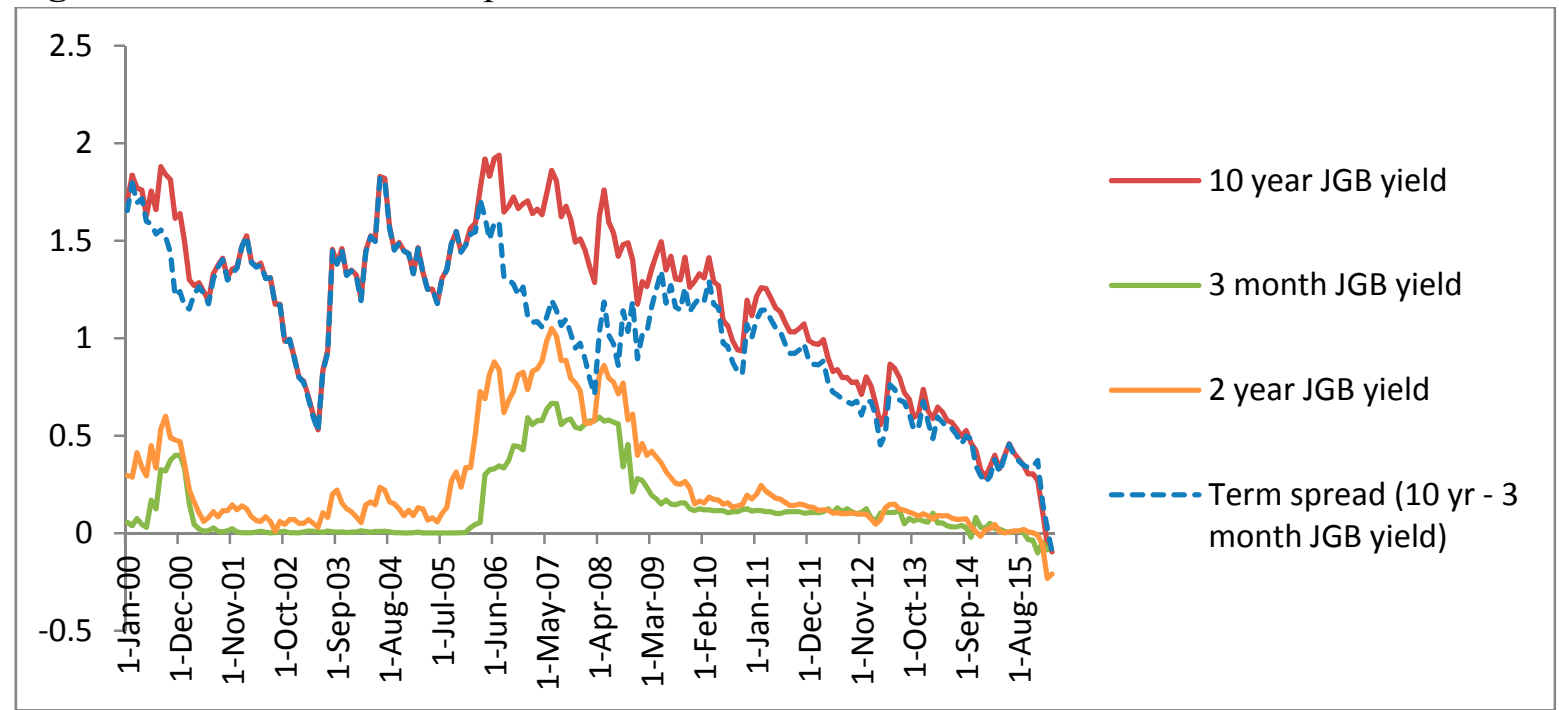

Source: IMF IFS

Nonetheless, we investigated the impact of a negative shock to Japan's interest rates. We respectively calculated the effect of one negative standard deviation shock to Japan's shortterm interest rate, the two-year government bond yield, the 10-year government bond yield,

\footnotetext{
${ }^{8}$ We also tried the alternative ordering described in Dees di Mauro, Smith and Pesaran (2007) by placing the policy variable as the last in the ordering block, and the results are in line with our first ordering. We also tried placing equity prices as the second variable in the ordering block.

${ }^{9}$ Placing the United States as the first country bloc will still yield very similar results.
} 
and the term spread (difference between the long-term and short-term yield). We found that our calculations yield no statistically significant results to Japan or the rest of the Emerging Asia's variables. In fact, the results do not reflect an increase in equity prices, nor a depreciation of the exchange rate in Japan.

Our findings lead us to believe that the transmission mechanism when the interest rates are around zero is indeed broken, and therefore interest rates cannot be used as proxies for monetary policy in that case.

\section{One positive standard deviation shock to Japan's monetary base}

We also re-estimated the model using a shock to Japan's monetary base as proxy for QQE. Using this variable does not yield strong or statistically significant results on financial variables, although a one standard deviation increase in the monetary base consistently yields a significant increase in inflation for Japan, of the order of 0.05 percent. There might be some technical reasons for the lack of spillovers when one uses this variable as proxy of QQE. One possible interpretation of our results is that spillovers through QQE are transmitted mainly though expectations - captured in our estimations when we proxy it by a movement in equity prices - rather than by balance sheet adjustments captured by movements in the monetary base. The limited spillovers from the monetary base shock are also possibly due to the fact that the money injected into Japanese banks through the purchase of JGBs is not being circulated into the economy, given that the banks are not channeling the money into lending but rather keeping it in cash holdings.

\section{One positive standard deviation shock to Japan's equity prices}

Figure 3 shows the responses of one positive standard deviation shock to Japan's equity prices. The median estimates are reported in solid lines, while dotted lines show the 90 percent confidence bands.

Regarding the domestic impact of Japanese QQE, our results suggest that it caused an equity price boom, an economic recovery, depreciation of the yen, but with limited impact on inflation. GDP increased by 0.5 percent. Equity prices rose approximately by 5 percent. ${ }^{10}$ Inflation picked up slightly by 0.05 percent, with the increase not being statistically significant. Bank credit was largely unmoved. The exchange rate depreciated by 1 to 1.5 percent $^{11}$, and remained at those levels for the remaining periods. The strongest short-term impact was in terms of capital inflows, which in the first two periods increased by about 30 percent in Japan. The increase in capital inflows reflects the depth of the initial impact of Abenomics on investor confidence, with higher equity prices raising expectations of higher future growth. Thus, the stock-price increase associated with QQE and the pick-up in the economy made Japan a more attractive destination for foreign investors.

\footnotetext{
${ }^{10}$ All variables are in natural logarithm, and are first adjusted to inflation.

${ }^{11}$ The decreasing impulse response function of Japan's exchange rate reflects depreciation since we are using the nominal effective exchange rate for Japan.
} 
Turning to spillovers, our results suggest that QQE caused a significant increase in equity prices in emerging Asia. For China, Indonesia, Malaysia, Singapore, Thailand, and Indonesia, the increase was in the 2-5 percent range. Outside Asia, QQE also positively impacted equity prices in the U.S., the Euro zone, and advanced European countries by about 1 percent. We interpret this result as suggesting that QQE impacts other countries through a confidence effect on expectations, which is reflected in the equity price increase.

Figure 3 also shows that, all the countries included in the sample, except for Norway ${ }^{12}$, experienced appreciation of their currency vis-à-vis the yen. According to the traditional expenditure switching effect, this should result in an increase in Japan's net exports at the other countries. Despite this, the impact of QQE on growth in the GDP of the remaining countries was generally positive, and for Indonesia, Malaysia, the Philippines, and Thailand, statistically significant. This could suggest that the switching away from domestic goods toward Japanese ones did not happen. Indeed, there is some evidence that, due to off-shore production of Japanese products, Japanese exports have become less sensitive to the exchange rate (see Kang 2015). Indeed, Japan's net exports only changed from -117 to -120 billion U.S. dollars from 2013 to 2014 . Furthermore, higher equity prices could also have boosted consumption through a wealth effect in Emerging Asia by raising the outlook for future growth.

Our results also show that there were positive spillovers from QQE which could have more than compensated the negative expenditure switching effect. In particular, QQE could have stimulated growth in other countries through the confidence effect discussed above. In addition, the positive effect of QQE on Japan's GDP would also positively affect growth in other countries through higher demand for their exports.

The impact on China illustrates how the confidence channel can dominate the exchange rate channel. The trade and financial linkages between Japan and China are amongst the strongest in the sample, but, despite the fact that China experienced an appreciation of its currency, the effect on GDP was positive, though not significant. In fact, the Japanese Yen depreciation and corresponding RMB appreciation brings a benefit of lower import costs of intermediate inputs given that Japan is one of the most important intermediate input suppliers for China in the global value chain. In other words, despite the depreciation of the Yen and the appreciation of the RMB, the overall spillover impact of QQE on China's GDP was not negative, due to increased confidence as illustrated by the increase in equity prices, and a reduction in import costs.

For the U. S., the impact of QQE is only statistically significant on equity prices, suggesting that, while QQE positively affected expectations in the U.S., Europe, as well as in Asia, the positive confidence effect in the U.S. did not have a significant impact on other U.S. macro variables. The impact of QQE on Europe was also mainly on equity prices, though we saw an appreciation of the exchange rate, and some increase of capital inflows during the first

\footnotetext{
${ }^{12}$ Norway's depreciation is presumably due to the Norwegian Kroner being a petroleum currency.
} 
period. Our results also suggest that QQE did not have any significant permanent spillover effect on inflation. While countries might experience a statistically significant increase in inflation in the first month (by about 0.05 percent), but this effect does not persist.

While the impact on GDP tended to be positive, our results pointed to country-specific heterogeneous responses to bank credit, and the effect tended not to be statistically significant. Changes in bank credit also depended on the shift between demand and supply of loans: An improvement in economic conditions could potentially increase the demand for loans. However, as inflation pushes down real interest rates, the increase in equity prices might shift investment from loans to the stock market, which would be perceived as more profitable.

Effects on capital inflows were less heterogeneous. For most countries, we observed a spike in the already present influx of flows to Southeast Asia in the first month after Abenomics. Capital inflows tended to peak in the first two periods, as high as 10 percent in Indonesia and 15 percent in Thailand, before going back to close to their original levels. This increase was statistically significant for most countries only for the first period, suggesting that the impact of Abenomics on capital flows was limited. As for China, we registered capital outflows. This could be because foreign investors were redirecting their investments towards Japan. Moreover, the large presence of Japanese companies in Indonesia and Thailand could explain a spillover of capital inflows into those countries.

Figure 3: Structural generalized impulse responses of a Positive unit $(+1 \sigma)$ shock to Japan's equity prices, (Bootstrap mean estimates with 90 percent confidence bounds)

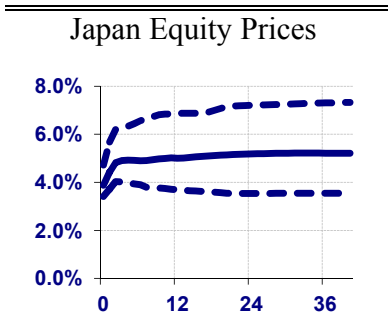

China Equity Prices

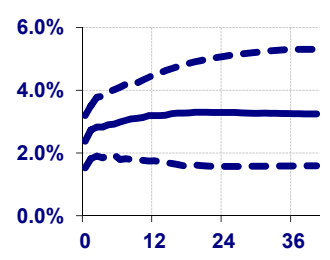

Euro Equity Prices

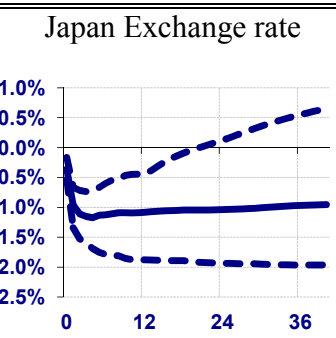

China Exchange rate

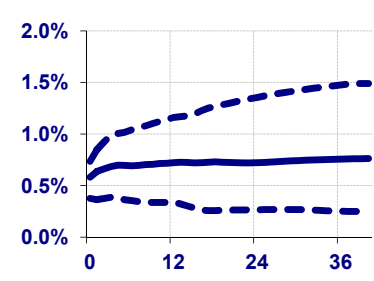

Euro Exchange rate

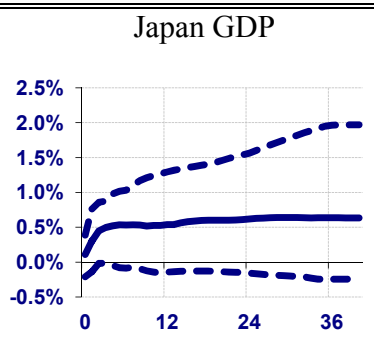

China GDP

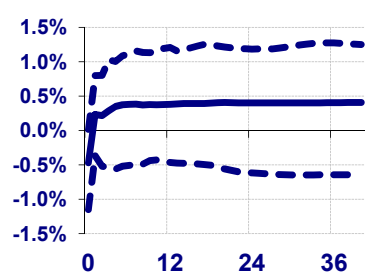

Euro GDP

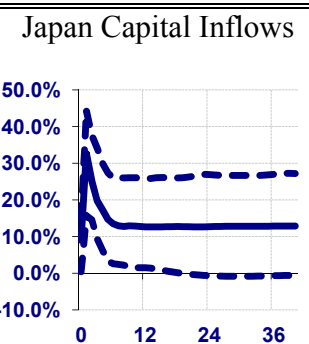

China Capital Inflows

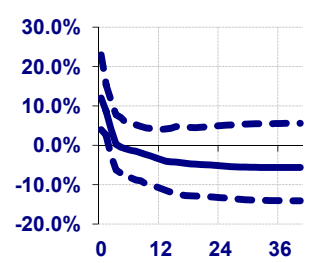

Euro Capital Inflows 


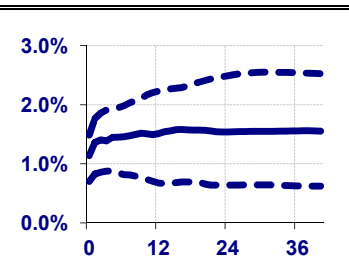

Indonesia Equity Prices

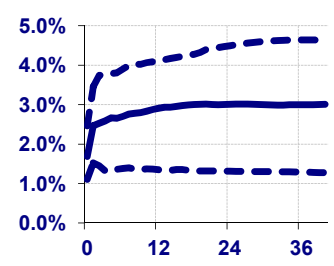

Malaysia Equity Prices

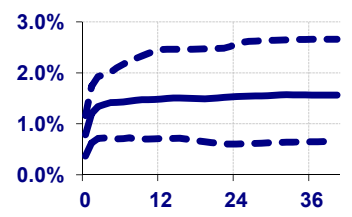

Norway Equity Prices

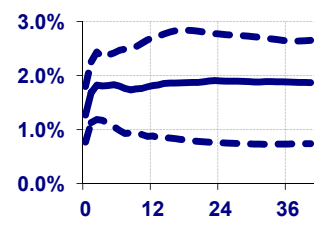

Philippines Equity Prices

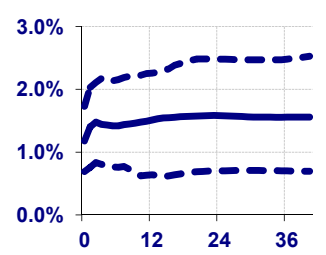

Singapore Equity Prices

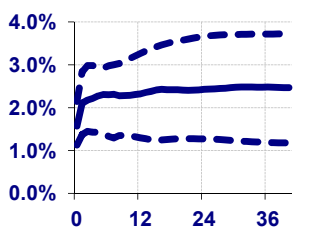

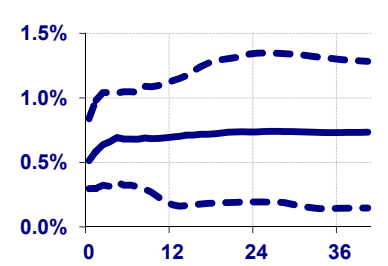

Indonesia Exchange rate

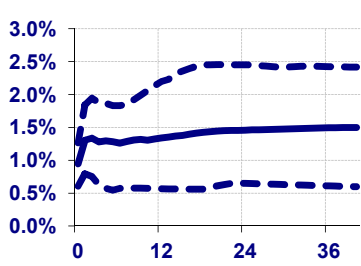

Malaysia Exchange rate

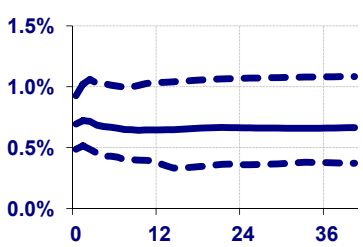

Norway Exchange rate

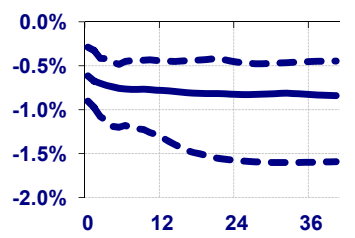

Philippines Exchange rate

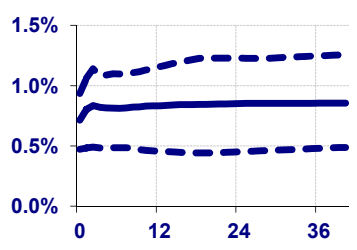

Singapore Exchange rate

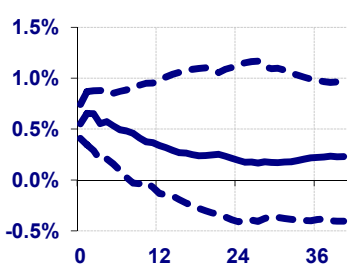

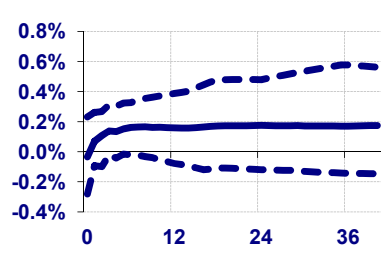

Indonesia GDP

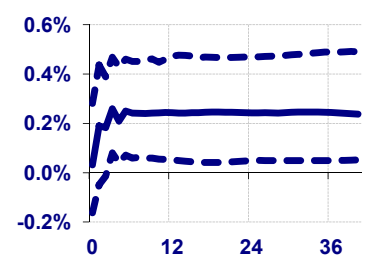

Malaysia GDP

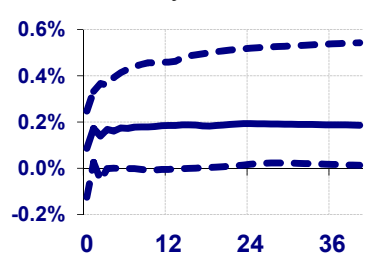

Norway GDP

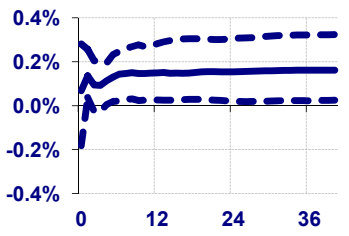

Philippines GDP

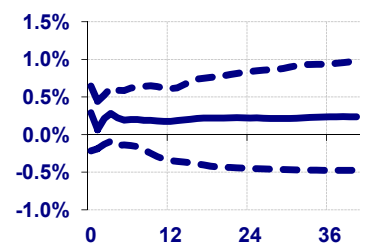

Singapore GDP

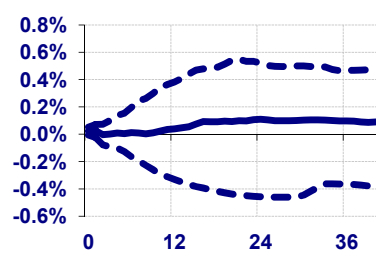

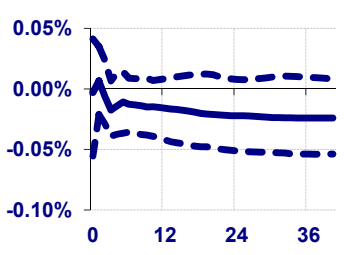

Indonesia Inflation

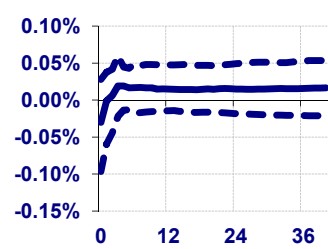

Malaysia Inflation

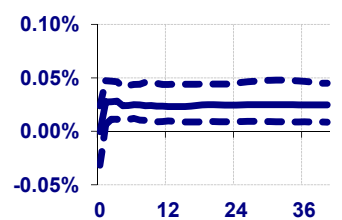

Norway Inflation

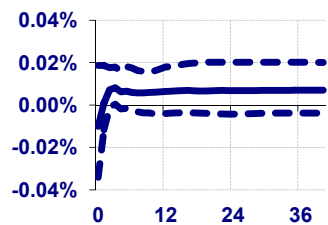

Philippines Inflation

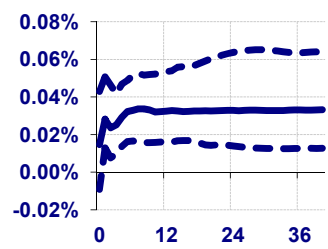

Singapore Inflation

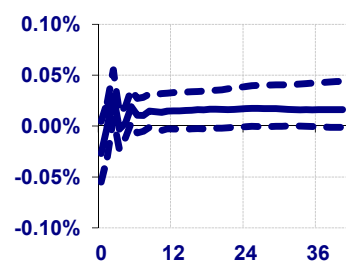

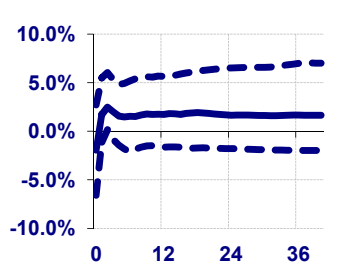

Indonesia Capital Inflows

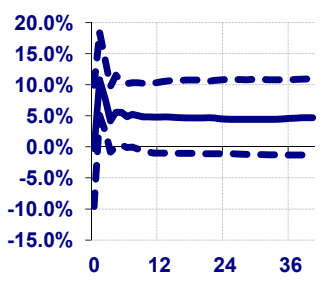

Malaysia Capital Inflows

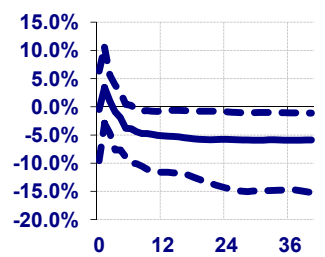

Norway Capital Inflows

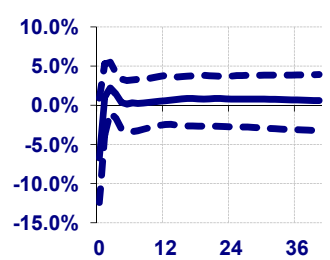

Philippines Capital Inflows

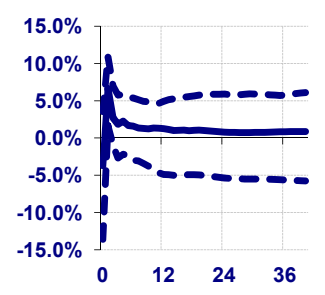

Singapore Capital Inflows

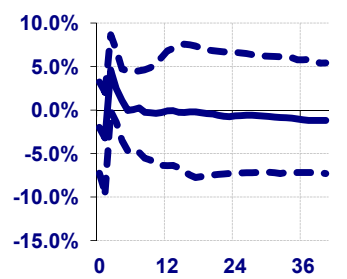




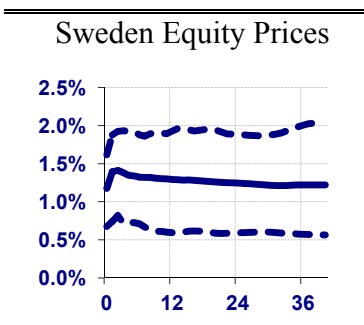

Switzerland Equity Prices

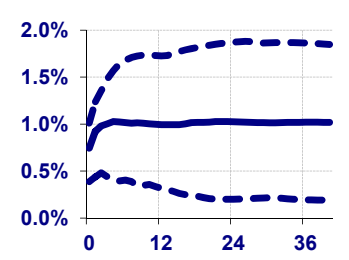

Thailand Equity Prices

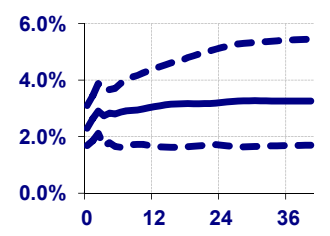

UK Equity Prices

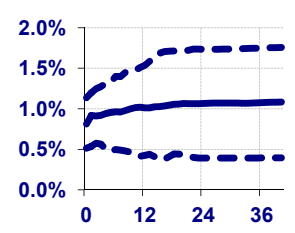

USA Equity Prices

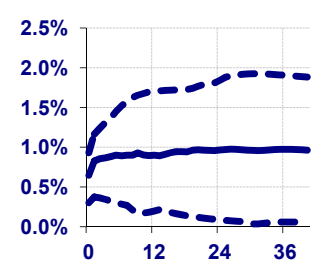

Sweden Exchange rate

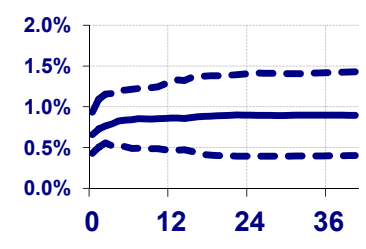

Switzerland Exchange rate

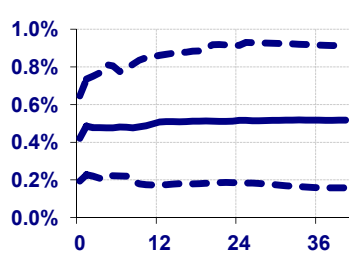

Thailand Exchange rate

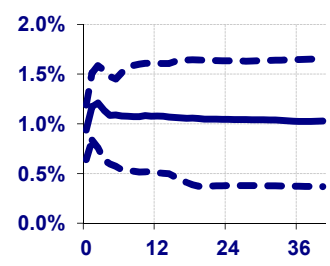

UK Exchange rate

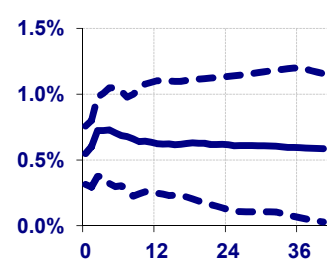

USA Exchange rate

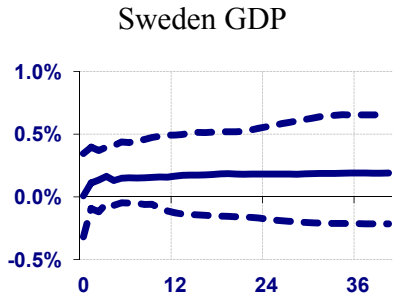

Switzerland GDP

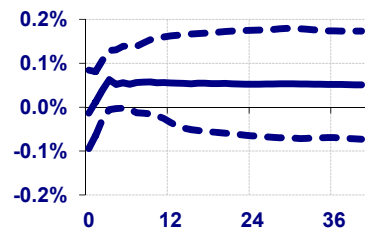

Thailand GDP

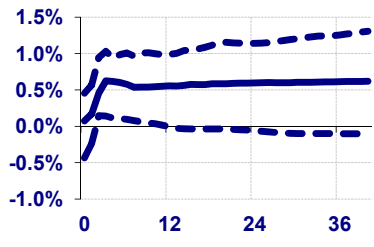

UK GDP

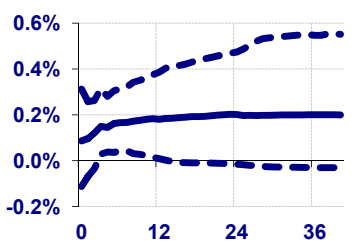

USA GDP

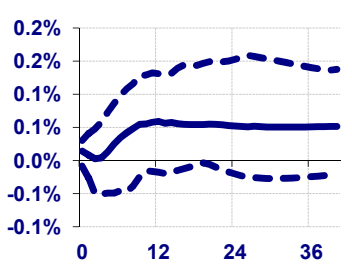

Sweden Inflation

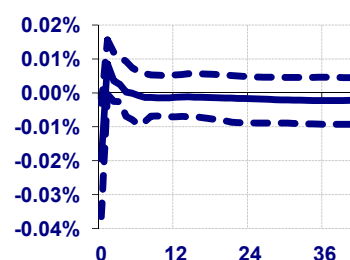

Switzerland Inflation

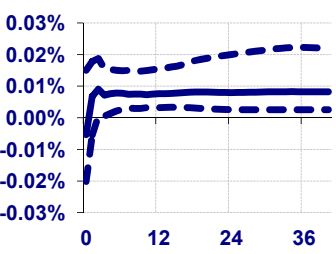

Thailand Inflation

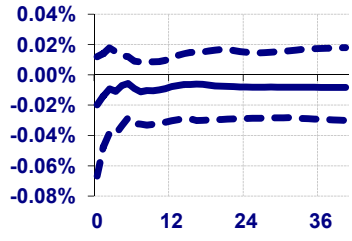

UK Inflation

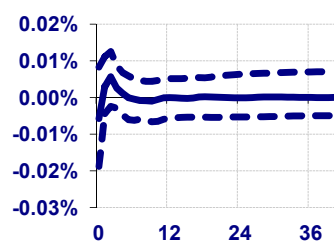

USA Inflation

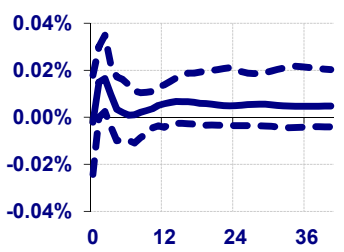

Sweden Capital inflows

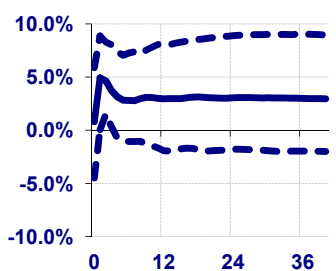

Switzerland Capital inflows

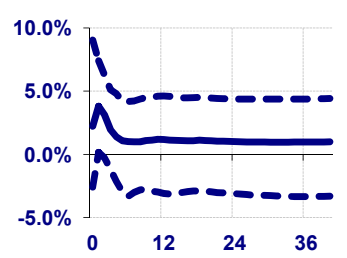

Thailand Capital inflows

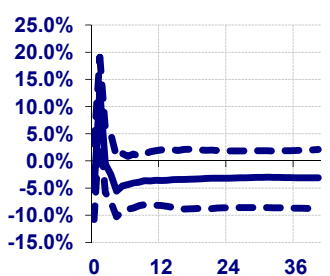

UK Capital inflows

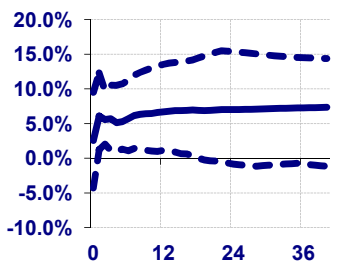

USA Capital inflows

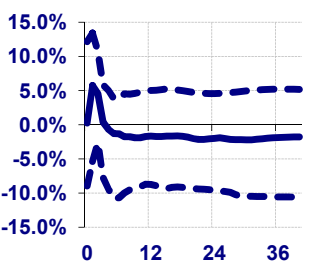

\section{COUnTERfaCtual ANALYSIS}

We conduct counterfactual analysis in order to assess the spillovers of Japanese QQE on Asia. The purpose of this exercise is to visualize the growth path of our variables had QQE 
not been implemented. We make conditional forecasts for our variables based on the assumption that Japan's equity prices had remained the same. We also experiment with keeping the monetary base constant. When we compare our forecasts to the actual data, we can assess the magnitude of the spillovers from Japan's QQE. We conduct our conditional forecasts by relying on the GVAR's one-step-ahead projections. From equation (8) in the technical appendix, we can see how endogenous variable $\mathrm{x}$ is expressed as the sum of lagged explanatory domestic and foreign variables and residuals. Therefore, we can conduct our counterfactual analysis from time $\mathrm{t}$, to estimate a future value of $\mathrm{x}$, on the estimate that equity prices had remained constant.

We chose to report the results of the counterfactual analysis on the ASEAN countries and China only, on output, the exchange rate and equity prices because these variables were the most affected by a standard deviation shock to Japan's equity prices. Results for other variables are available upon request. As for Japan, we include the counterfactual analysis on inflation.

Figure 4: Counterfactual Analysis of QQE on Japan:
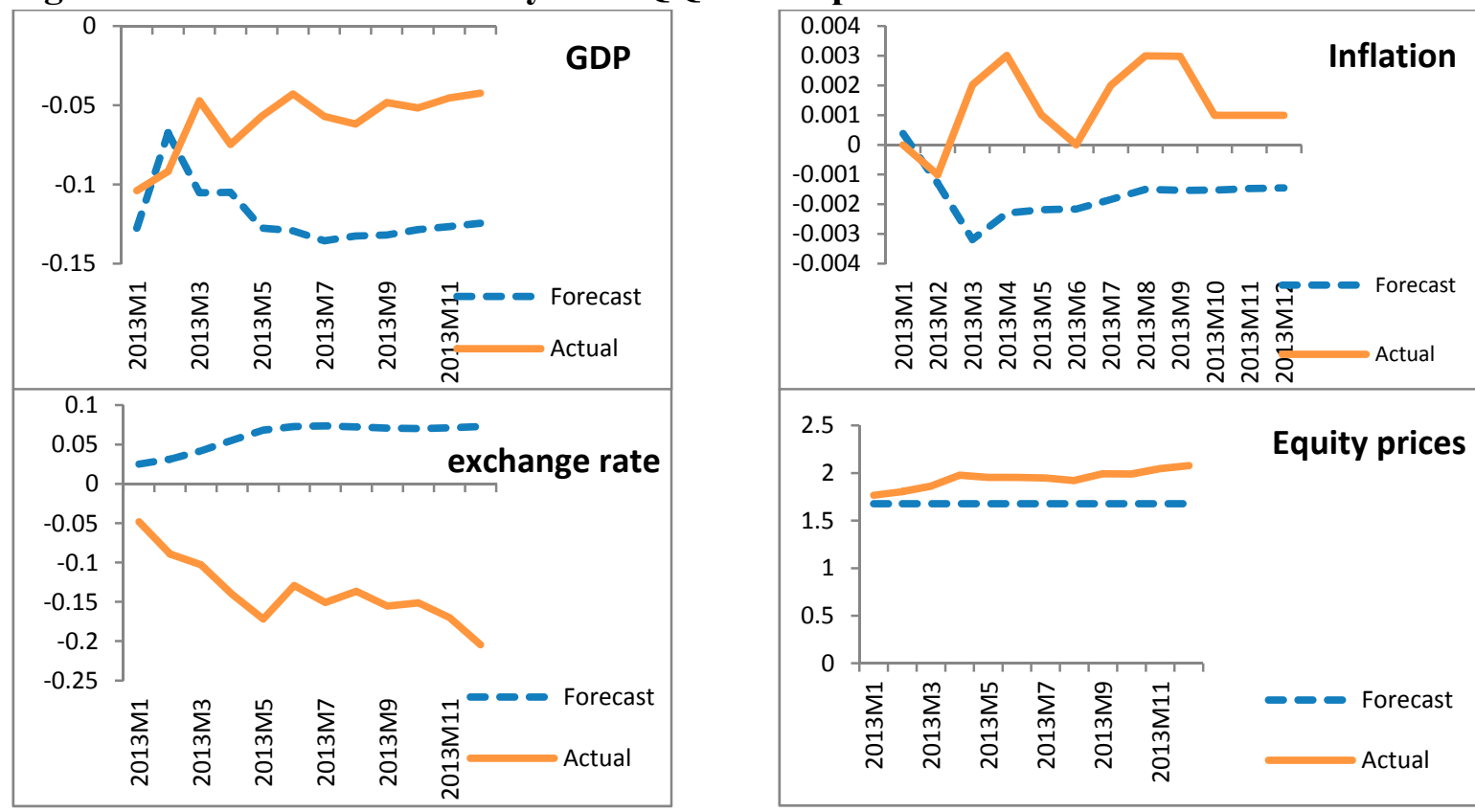

Figure 4 presents the results of our counterfactual analysis if equity prices had not changed since the first quarter of 2013. Our counterfactual analysis suggests that Japan's QQE had a significant impact on equity prices, the exchange rate and GDP. For Japan, inflation was also significantly affected by the increase in equity prices. Results show that had it not been for the growth in equity prices, Japan would not have experienced a depreciation of the exchange rate, nor an increase in inflation. Output was also positively affected.

Figure 5: Counterfactual Analysis of QQE on China: 


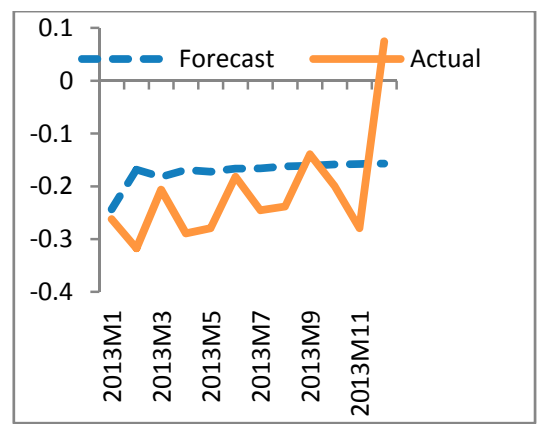

GDP

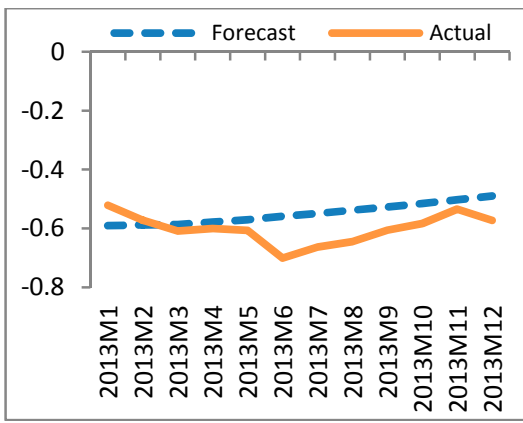

Equity prices

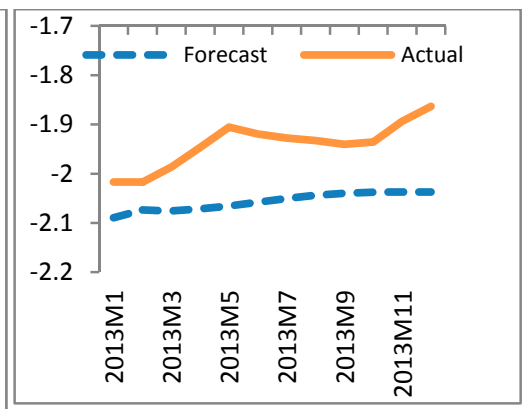

Exchange Rate

Figure 6: Counterfactual Analysis of QQE on Indonesia:

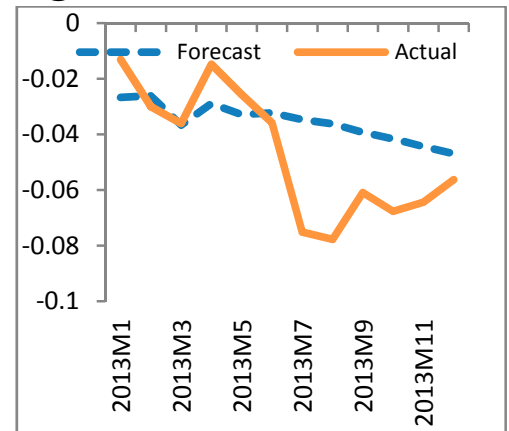

GDP

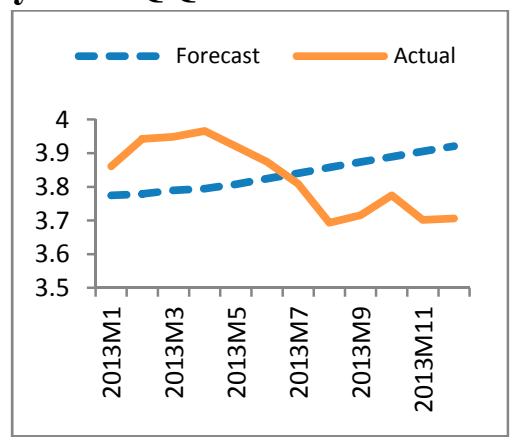

Equity prices

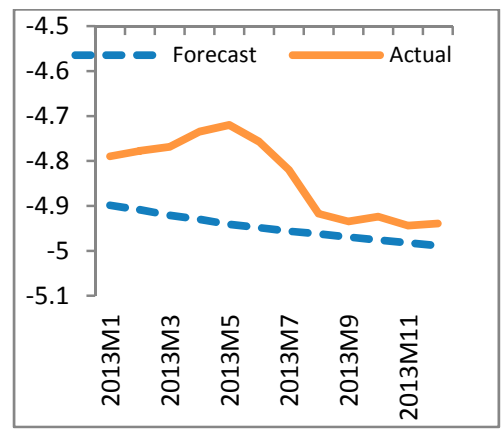

Exchange Rate

Figure 7: Counterfactual Analysis of QQE on Malaysia:

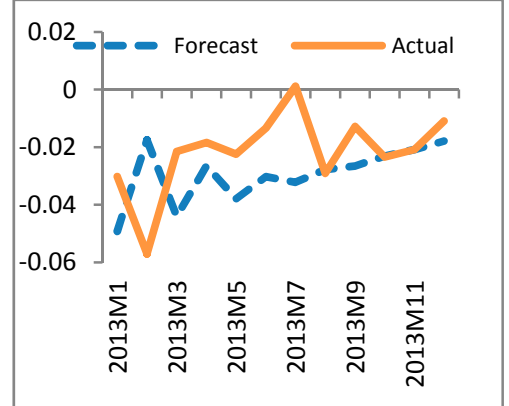

GDP

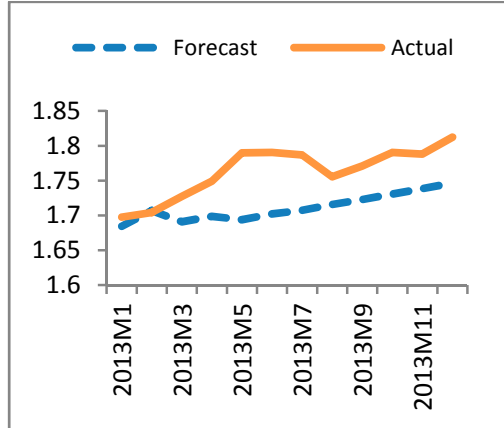

Equity prices

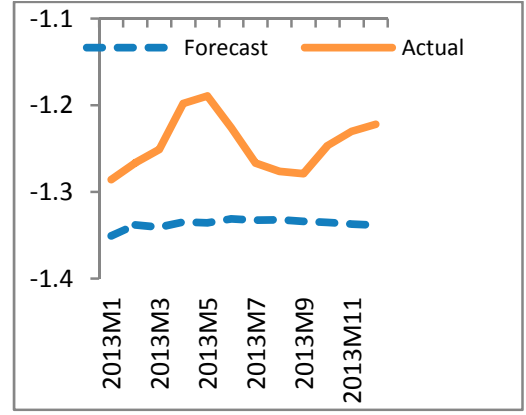

Exchange Rate

Figure 8: Counterfactual Analysis of QQE on the Philippines:

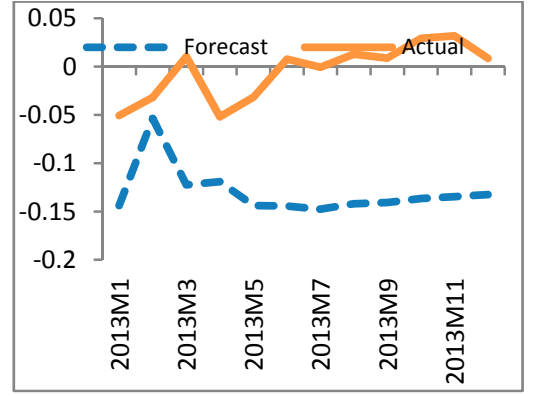

GDP

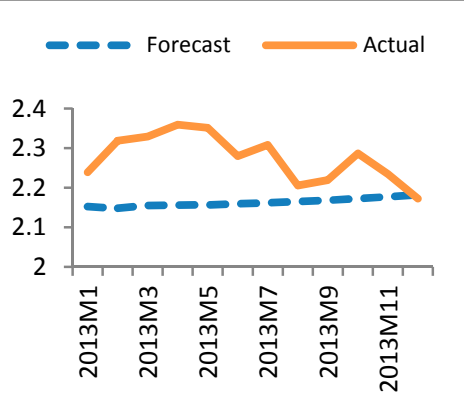

Equity prices

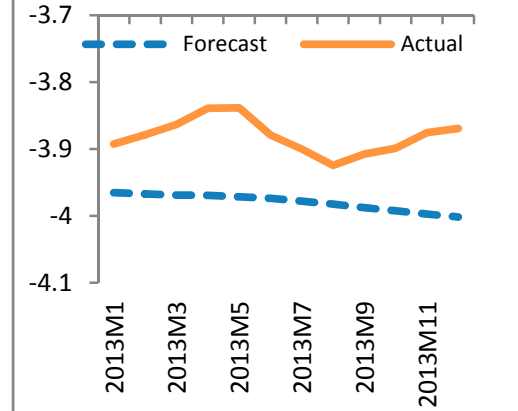

Exchange Rate 
Figure 9: Counterfactual Analysis of QQE on Singapore:

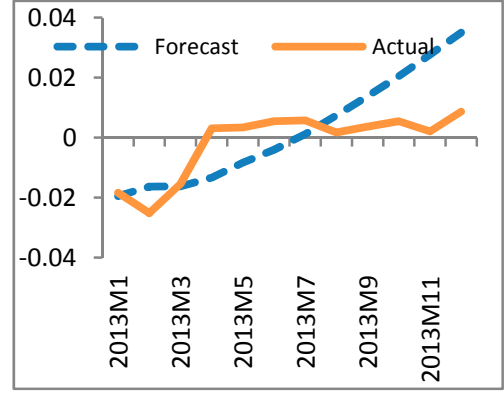

GDP

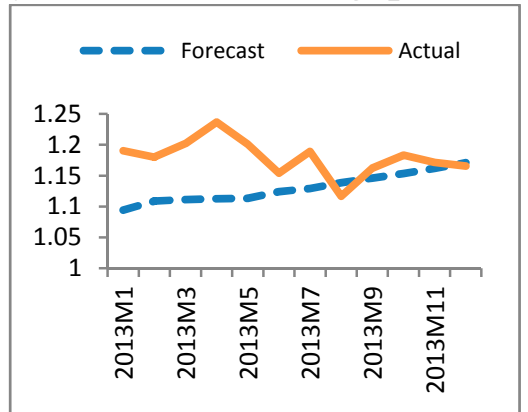

Equity prices

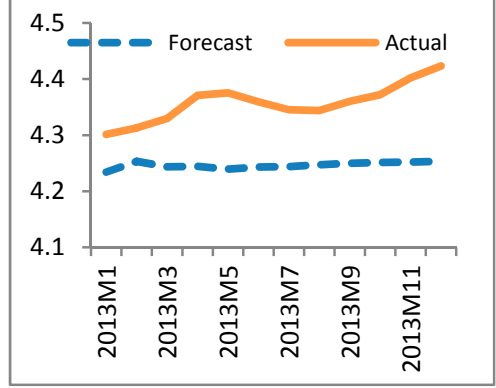

Exchange Rate

Figure 10: Counterfactual Analysis of QQE on Thailand:

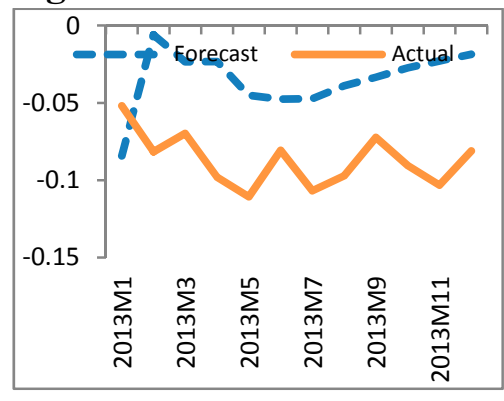

GDP

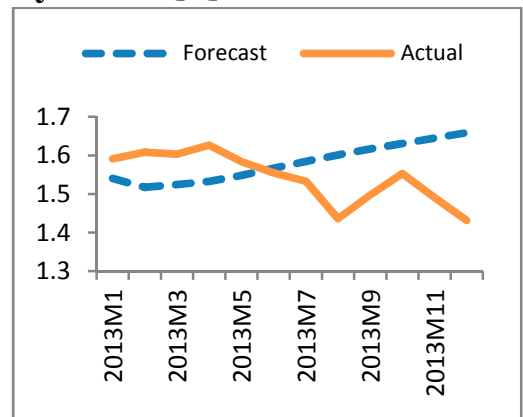

Equity prices

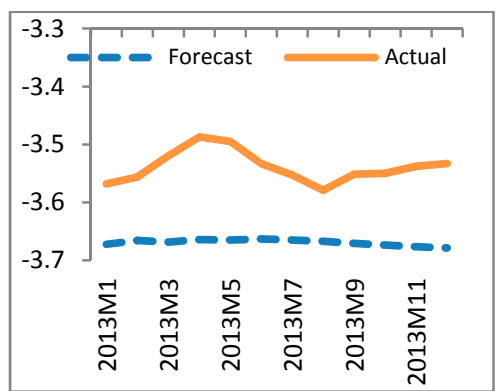

Exchange Rate

Figures 5-10 report the results of our counterfactual analysis, keeping equity prices constant from 2013 $\mathrm{M}^{1314}$. We see that for other than China and Thailand, countries' output would have been lower had equity prices remained constant in Japan. Moreover, all countries record equity prices higher than the forecasted equity prices. Finally, the counterfactual analysis reveals a currency appreciation in the region that also would have been lower if equity prices had remained low.

Of course, it is important to keep in mind that the actual values reflected in these graphs were also subject to other shocks, such as the June 2013 "tamper tantrum" as well the decline in oil prices (which can be seen by the distinctive dip in equity prices in 2013M06 for most countries). These external shocks can also be responsible for the decline in output and equity prices. Nonetheless, the results clearly indicate that spillovers from Japan's QQE were

\footnotetext{
${ }^{13} \mathrm{We}$ also ran different scenarios as robustness checks, such as keeping the monetary base constant from 2103M1, 2013M2, and keeping equity prices constant in 2013M2 as well. Then, we also tested to see if results are homogeneous with the monetary base and equity prices kept constant simultaneously for 2013M1 and 2013M2. Results are strongly robust.

${ }^{14}$ While Abenomics' QQE was effectively launched in April 2013, expectations started rising in the first quarter of the year due to speculation.
} 
present in ASEAN economies, and could have possibly reduced the impact of the "tamper tantrum" and price shocks in the region.

\section{Conclusion}

This paper has analyzed spillovers from Japan's Quantitative and Qualitative Easing (QQE) on emerging Asia. We used the recently developed GVAR model, which captures the financial and economic interactions of economies across trade and financial channels. We combined financial and trade channels in order to build weights to link the countries together and we explored spillovers through the bilateral trade channel and the foreign direct investment channel.

Countries included in our sample in addition to Japan were China, Indonesia, Malaysia, the Philippines, Singapore, and Thailand. We also included the U.S., the Eurozone and advanced European countries, because of the importance of their trade and financial links to Japan, and their dominant role in the world economy. Given that Japan's interest rates have been close to zero for long time, we chose to proxy QQE through an increase in equity prices, rather than trough a decrease in the nominal interest rate. We also re-estimated the model proxying QQE with increases in the monetary base. Shocks to Japan's equity prices were identified using structural impulse responses solved through a recursive Cholesky scheme. For a robustness check, we also imposed short-run identifying restrictions on Japan's cointegrating vectors.

Our analysis points to two conclusions. The first, and in our view main, result is that spillovers from QQE to emerging Asian countries tended to be positive. Despite an appreciation of domestic currencies vis-à-vis the yen, the impact on emerging Asia GDP was positive and significant. This suggests that the positive effect of QQE on expectations of future growth, by improving confidence, has more than offset any negative exchange rate spillover due to expenditure switching from domestic to Japanese goods. Emerging Asia also experienced limited spillovers in terms of higher inflation and, on average, increased capital inflows. Finally, re-estimating the model by proxying QQE with changes in the monetary base (rather than with an increase in equity prices) does not yield strong nor significant spillovers, suggesting that QQE affected other countries in Asia mostly through the impact of expectations and improvements in confidence, captured by the equity price variables, rather than through balance sheet adjustments which might have been captured by movements in the monetary base. 


\section{TECHNICAL APPENDIX}

\section{A. The GVAR model framework}

In following two sections, we discuss the econometric framework of the GVAR model, which was first proposed by Pesaran, Schuermann and Weiner (2004, hence PSW), and further developed by Dees, diMauro, Pesaran and Smith (2007, henceforth DdPS). The GVAR framework is well suited to examining spillovers because it allows us to model country-specific dynamics, while also allowing for cointegration among variables.

Assume an $\mathrm{N}$ number of countries $i=0,1 \ldots N$ to be included in the model. For each country, a t number of domestic variables $t=1,2 \ldots t$ such as GDP, inflation, equity prices, etc... are collected into a $x_{i t}: k_{i} \times 1$ vector of domestic variables. Accordingly, an $x_{i t}^{*}: k_{i}^{*} \times 1$ vector of foreign variables is built for each $x_{i t}$, where:

$$
x_{i t}^{*}=\sum_{j=0}^{N} w_{i j} x_{j t}, w_{i i}=0
$$

With $w_{i j}, j=0,1, \ldots, N$ a set of weights such that $\sum_{j=0}^{N} w_{i j}=1$

Then for each country, a $\operatorname{VARX} *(2,2)$ structure will be constructed, where:

$$
x_{i t}=a_{i 0}+a_{i 1} t+\Phi_{i 1} x_{i, t-1}+\Phi_{i 2} x_{i, t-2}+\wedge_{i 0} x_{i t}^{*}+\wedge_{i 1} x_{i, t-1}^{*}+\wedge_{i 2} x_{i, t-2}^{*}+u_{i, t}
$$

With the $u_{i, t}$ cross-sectionally weakly correlated such that $\hat{\mathrm{u}}_{i t}=\sum_{j=0}^{N} w_{i j} u_{j t} \stackrel{p}{\rightarrow} \infty \quad(\stackrel{p}{\rightarrow}$ denotes convergence in probability ).

We therefore can write the error correction form of the $\operatorname{VARX} *(2,2)$ specification as such:

$$
\Delta x_{i t}=c_{i 0}-\alpha_{i} \beta^{\prime}{ }_{i}\left[z_{i, t-1}-\gamma_{i}(t-1)\right]+\Lambda_{i 0} \Delta x_{i t}^{*}+\Gamma_{i} \Delta z_{i, t-1}+u_{i t},
$$

where $z_{i t}=\left(x^{\prime}{ }_{i t}, x_{i t}^{*^{\prime}}\right)$,

$\alpha_{i}$ is a $k_{i} \times r_{i}$ matrix of rank $r_{i}$

and $\beta_{i}$ is a $\left(k_{i}+k^{*}\right) \times r_{i}$ matrix of rank $r_{i}$.

$\beta_{i}$ is then partitioned as $\beta_{i}=\left(\beta^{\prime}{ }_{i x}, \beta^{\prime}{ }_{i x *}\right)^{\prime}$ conformable to $z_{i t}$, in order to write the $r_{i}$ error correction terms as

$$
\beta^{\prime}{ }_{i}\left(z_{i t}-\gamma_{i} t\right)=\beta^{\prime}{ }_{i x} x_{i t}+\beta^{\prime}{ }_{i x} x_{i t}+\beta^{\prime}{ }_{i x *} x_{i t}^{*}-\left(\beta^{\prime}{ }_{i}-\gamma_{i}\right) t
$$


The foreign variables $x_{i t}^{*}$ and the global variables are estimated to be I(1) weakly exogenous variables: they are treated as 'long-forcing' with respect to the domestic variables of the VARX* model, i.e. there is no long-run feedback from the domestic variables to the foreign variables. All variables are tested for the presence of unit root by using the weighted symmetric ADF tests. With the use of the weak exogeneity test, we can check which foreign variables to include in our estimation.

Next, reduced rank regression is used in order to obtain the number of cointegrating relations $r_{i}$, the speed of adjustment coefficients $\alpha_{i}$, and the cointegrating vectors $\beta_{i}$ for each country's VARX*. The rank orders are obtained by Johansen's trace statistic. Thus, each VARX* is estimated, allowing for cointegrating within the domestic variables $x_{i t}$, and between the domestic and foreign variables $x_{i t}$ and $x_{i t}^{*}$.

Once $\beta_{i}$ is estimated, the remaining parameters of each country's VARX* can be obtained by OLS, using the following equation:

$$
\Delta x_{i t}=c_{i 0}+\delta_{i} E C M_{i, t-1}+\Lambda_{i 0} \Delta x_{i t}^{*}+\Gamma_{i} \Delta z_{i, t-1}+u_{i t}
$$

With $E C M_{i, t-1}$ as the model correction terms according to the $r_{i}$ cointegrating relations of the $i^{\text {th }}$ country model.

The lag order for domestic variables $\left(p_{i}\right)$ and foreign variables $\left(q_{i}\right)$ that are included in each country's VARX* model is selected using the Akaike Information Criterion (AIC), subject to a maximum lag order of $p_{i}=2$ that we chose.

Once each country-specific VARX* model is estimated, we can solve the GVAR model for the world as a whole: when the GVAR is solved for the world as a whole, all the variables become endogenous to the system, i.e. the GVAR model is expressed in terms of a $k \times 1$ global variable vector, $k=\sum_{i=0}^{N} k_{i}$

By calling on $z_{i t}=\left(\begin{array}{c}x_{i t} \\ x_{i t}^{*}\end{array}\right)$, we can rewrite each economy's VECMX model as:

$$
A_{i 0} z_{i t}=a_{i 0}+a_{i 1} t+A_{i 1} z_{i t-1}+\cdots+A_{i p_{i}} z_{i t-p_{i}}+u_{i t}
$$

Where

$$
A_{i 0}=\left(\mathrm{I}_{k_{i}},-\Lambda_{i 0}\right), \quad A_{i j}=\left(\Phi_{i j}, \Lambda_{i j}\right) \text { for } j=1, \ldots, p_{i}
$$

We then use the weights $w_{i j}$, which we obtained from the trade or financial flows, in order to create the link matrix $W_{i}$. Using the link matrix $W_{i}$, we obtain the identity:

$$
z_{i t}=W_{i} x_{t}
$$


Where $x_{t}=\left(x^{\prime}{ }_{0 t}, x^{\prime}{ }_{1 t}, \ldots, x^{\prime}{ }_{N t}\right)^{\prime}$ is the $k \times 1$ vector of all endogenous variables of the system, and $W_{i}$ is the $\left(k_{i}+k_{i}^{*}\right) \times k$ matrix that captures all bilateral exposures between the countries in the dataset.

Finally, the individual models are stacked to yield the model for all the variables in the global model $x_{t}$ given by:

$$
G_{o} x_{t}=a_{0}+a_{1 t}+G_{1} x_{t-1}+\cdots+G_{p} x_{t-p}+u_{t}
$$

where,

with $p=\max \left(\max p_{i}, \max q_{i}\right)$

$$
\begin{aligned}
& G_{0}=\left(\begin{array}{c}
A_{00} W_{0} \\
A_{10} W_{1} \\
\vdots \\
A_{N 0} W_{N}
\end{array}\right), G_{j}=\left(\begin{array}{c}
A_{0 j} W_{0} \\
A_{1 j} W_{1} \\
\vdots \\
A_{N j} W_{N}
\end{array}\right), \text { for } j=1, \ldots, p \\
& a_{0}=\left(\begin{array}{c}
a_{00} \\
a_{10} \\
\vdots \\
a_{N 0}
\end{array}\right), a_{1}=\left(\begin{array}{c}
a_{01} \\
a_{11} \\
\vdots \\
a_{N 1}
\end{array}\right), u_{t}=\left(\begin{array}{c}
u_{0 t} \\
u_{1 t} \\
\vdots \\
u_{N t}
\end{array}\right)
\end{aligned}
$$

Premultiplying Equation 8 by $G_{0}^{-1}$, the GVAR(p) model can be expressed as

$$
x_{t}=b_{0}+b_{1} t+F_{1} x_{t-1}+\cdots+F_{p} x_{t-p}+\varepsilon_{t},
$$

where

$$
\begin{gathered}
b_{0}=G_{0}^{-1} a_{0}, b_{1}=G_{0}^{-1} a_{1}, \\
F_{j}=G_{0}^{-1} G_{j}, j=1, \ldots, p, \varepsilon_{t}=G_{0}^{-1} u_{t}
\end{gathered}
$$

Equation (9) can be solved recursively and impulse response and variance decomposition analysis can then be performed.

\section{B. GVAR estimation}

We use the GVAR toolbox by Vanessa Smith and Alesandro Galesi ${ }^{15}$ in order to estimate our model. The order of integration for foreign and domestic variables is obtained by testing for

\footnotetext{
${ }^{15}$ The GVAR toolbox is available for download from wwwcfap.jbs.cam.ac.uk/research/gvartoolbox/index.html.
} 
unit root. All variables are tested with the Augmented Dickey-Fuller test as well as the Weight Symmetric ADF test on levels, first and second differences. Results are available upon request. We find that for the majority of the variables, the hypothesis of unit root cannot be rejected. All variables are tested for weak exogeneity, and the majority of foreign variables are weakly exogenous. Choosing to exclude non-exogenous variables from the VARX* specification has no statistically significant impact on the results. The trend coefficients are restricted to lie in the cointegrating space, and the intercepts are left unrestricted. (This is case IV in the GVAR toolbox).

In addition, our model satisfies the additional requirements indicated by PSW (2004):

- The GVAR is stable: the eigenvalues of the F matrix in (9) lie on or inside the unit circle.

- The weights are relatively small: PSW states that the weights must be small such that $\sum_{j=1}^{N} w_{i j}^{2} \rightarrow 0$ as $N \rightarrow \infty$. Most of our weights satisfy this condition.

- The idiosyncratic shocks are weakly correlated. We can check for weak correlation by calculating the average pair-wise cross-section correlation between residuals and variables. The VECMX* residuals show low correlation among all variables. 


\section{References:}

Bauer M., Neely C. 2014. International channels of the Fed's unconventional monetary policy. Journal of International Money and Finance 44, 24-46.

Blinder, A., 2010. Quantitative easing: entrance and exit strategies. Federal Reserve Bank of St. Louis Review, November/December.

Botman D., 2015. Abenomics: lessons learned from two decades of conventional and unconventional monetary policies. In "Can Abenomics succeed? Overcoming the legacy of Japan's lost decades.", IMF.

Chen Q., Filardo A., Dong H., Feng Z. 2015, Financial crisis, US unconventional monetary policy and international spillovers, IMF working paper WP/15/85

Chen Q., Lombardi M., Ross A., Feng Z., 2015. Global impact of US and Euro area unconventional monetary policies: a comparison

Chudik, A., Fratzscher, M. 2011. Identifying the global transmission of the 2007-2009 financial crises in a GVAR model. European Economic Review 55, 325-339

Cooley, T. F and V. Quadrini (1999a), Monetary Policy and the Financial Decisions of Firms, mimeo.

Dees, S., di Mauro, F., Smith, V., Pesaran, H., 2007. Exploring the international linkages of the euro area: a global VAR analysis. J. Appl. Econ. 22(1), 1-38.

Eggertsson, G. , 2008. Great Expectations and the End of the Depression. American Economic Review, 98 (4), 1476-1516.

Eickmeier, S., Ng T., 2011. How do credit supply shocks propagate internationally? A GVAR approach. CEPR Discussion Paper, 8720.

Fujiawara I., Nakazono Y., Ueda K., 2014. Policy Regime Change against Chronic Deflation? Policy option under a long-term liquidity trap. RIETI Discussion paper series 14E-019

IMF Regional Economic Outlook April 2015. Asia and Pacific, Stabilizing and Outperforming Other Regions.

Galesi A., Sgherri S. 2009. Regional financial spillovers across Europe: A Global VAR analysis. IMF working paper WP/09/03 
Gambacorta L., Hofman B., Peersman G., 2014. The effectiveness of unconventional monetary policy at the zero lower bound: A cross-country analysis. Journal of Money, Credit and Banking, Vol. 46, No. 4

Glick R., Leduc S., 2012. Central bank announcements of asset purchases and the impact on global financial and commodity markets. Journal of International Money and Finance 31, 2078-2101

Hosono K., Isobe S., 2014. The financial market impact of unconventional monetary policies in the U.S., the U.K., the Eurozone, and Japan. PRI discussion paper series No.14A-05

Kang, J. S., 2015, “What explains Japan's export sluggishness?” Box 1 in "Japan: Staff Report for the 2015 Article IV Consultation, forthcoming IMF Country Report.

Lam R.W., 2011. Bank of Japan's monetary easing measures: Are they powerful and comprehensive? IMF working paper WP11.264

Lastrapes, W., D. 1998. International Evidence on Equity Prices, Interest Rates and Money, Journal of International Money and Finance, Vol. 17, No. 3, pp. 377-406.

Neri S. , 2004, Monetary policy and stock prices : theory and evidence. Banca D’Italia, Working paper number 513

Pesaran, M.H., Schuermann, T., Weiner, S., 2004. Modeling regional interdependencies using a global error-correcting macroeconometric model. J. Bus. Econ. Stat. April.

Rapach, D., E. 2001. Macro Shocks and Real Stock Prices, Journal of Economics and Business, Vol. 53, pp. 5-26.

Ree, Joo K., Choi S. 2014, Safe-Haven Korea? - Spillover Effects from UMPs, IMF working paper WP/14/53

Ree, Joo K., Hong G., Choi S. 2015, Should Korea worry about a permanently weak Yen? , IMF working paper WP/15/158

Ueda, K., 2012. The Effectiveness of Non-Traditional Monetary Policy Measures: The Case of the Bank of Japan. Japanese Economic Review 63(1), 1-22.

Yan S., Frigyes F., Giang H., 2013. Cross-Country Linkages in Europe: A Global VAR Analysis. IMF working paper, WP/13/194 
Data Appendix

\begin{tabular}{|c|c|c|c|}
\hline Variable & Description & Source & Notes \\
\hline Real GDP (y) & $y=\ln \frac{G D P_{i t}}{C P I_{i t}}$ & IMF IFS & $\begin{array}{l}\text { The monthly time } \\
\text { series are obtained } \\
\text { using the Chow-Lin } \\
\text { interpolation method, } \\
\text { with the Industrial } \\
\text { production index as a } \\
\text { reference. ( } \\
\text { seasonally adjusted } \\
\text { using Eviews X13) }\end{array}$ \\
\hline CPI inflation (dp) & $d p=\ln \left(C P I_{i t}\right)-\ln \left(C P I_{i, t-1}\right)$ & IMF IFS & \\
\hline Equity prices (eq) & $e q=\ln \frac{E Q_{i t}}{C P I_{i t}}$ & Bloomberg & $\begin{array}{l}\text { The MSCI index for } \\
\text { each country is used. }\end{array}$ \\
\hline Exchange rate (ex) & $e x=\ln \frac{E_{i t}}{C P I_{i t}}$ & $\begin{array}{l}\text { Bloomberg } \\
\text { and the } \\
\text { BIS for } \\
\text { Japan }\end{array}$ & $\begin{array}{l}\text { The exchange rate vis- } \\
\text { à-vis the Japanese yen } \\
\text { (cross-rate) is used for } \\
\text { all Asian countries. } \\
\text { For Japan, we use the } \\
\text { nominal effective } \\
\text { exchange rate }\end{array}$ \\
\hline Monetary base (mb) & Monetary base, percent. & IMF IFS & \\
\hline $\begin{array}{l}\text { Short-term interest } \\
\text { rate }(r)\end{array}$ & $\mathrm{r}=0.25^{*} \ln \left(1+R_{i t}^{S} / 100\right)$ & IMF IFS & $\begin{array}{l}\text { - For China, the } \\
\text { deposit rate is used. } \\
\text { - For Malaysia, the } \\
\text { Philippines, the } \\
\text { treasury bill rate is } \\
\text { used. } \\
\text { - For Japan, Indonesia, } \\
\text { Thailand, the money } \\
\text { markets rate is used. }\end{array}$ \\
\hline Bank credit (bc) & $b c=\ln \frac{B C_{i t}}{C P I_{i t}}$ & IMF IFS & $\begin{array}{l}\text { Claims on the private } \\
\text { sector (seasonally } \\
\text { adjusted using Eviews } \\
\text { X13) }\end{array}$ \\
\hline Price of Oil & $\begin{array}{l}\text { US dollars per barrel, in } \\
\text { natural logarithm }\end{array}$ & IMF IFS & \\
\hline Imports and Exports & In millions of U.S. Dollars & IMF CDIS & $\begin{array}{l}\text { Direction of Trade } \\
\text { statistics }\end{array}$ \\
\hline Portfolio flows & In millions of U.S. Dollars & IMF CPIS & $\begin{array}{l}\text { Coordinated Portfolio } \\
\text { Investment Survey }\end{array}$ \\
\hline FDI flows & In millions of U.S. Dollars & IMF & $\begin{array}{l}\text { Coordinated Direct } \\
\text { Investment Survey }\end{array}$ \\
\hline
\end{tabular}




\begin{tabular}{|l|l|l|l|}
\hline Capital inflows & In millions of U.S. Dollars & $\begin{array}{l}\text { Haver } \\
\text { Analytics } \\
\text { (EPFR } \\
\text { Asia) }\end{array}$ & $\begin{array}{l}\text { Capital flows are the } \\
\text { sum of Equity flows } \\
\text { and bond flows. For } \\
\text { the years that data for } \\
\text { one series is } \\
\text { unavailable, we just } \\
\text { use the data from the } \\
\text { other series. }\end{array}$ \\
\hline
\end{tabular}

